\title{
OVĚŘENÍ FYZIKÁLNĚ-MECHANICKÝCH VLASTNOSTÍ POLYMERNÍCH LEPICÍCH HMOT
}

\author{
ASSESSMENT OF PHYSICAL-MECHANICAL PROPERTIES OF \\ POLYMER ADHESIVE MATERIALS
}

\author{
Radek Hermann ${ }^{1}$, Jana Majerová ${ }^{1}$, Petr Figala ${ }^{1}$ \\ ${ }^{1}$ Fakulta stavební VUT v Brně, Brno University of Technology, Veveř́ 331/95, Czech Republic
}

\begin{abstract}
Abstrakt
Tento článek se zabývá problematikou polymerních lepicích malt. V této studii byly použity vinyl-esterové a epoxidové pryskyřice v kombinaci s křemenným plnivem. Tato práce studuje fyzikálně-mechanické vlastnosti vyvinutých malt. Pevnost v tlaku, ohybu a otěruvzdornosti. Pro každou maltu byl zjištěn maximální plnicí poměr při zachování použitelnosti zednickým způsobem (špachtlí či lžící). Výsledky ukazují, že epoxidová malta na bázi aminu vykazuje nižší fyzikálně-mechanické vlastnosti než lepicí malta na bázi vinylesteru, kromě odolnosti proti obrusu, u níž dosáhla hmota na bázi epoxidu výrazně lepších výsledků.
\end{abstract}

\section{Klíčová slova}

Lepicí hmota, polymer, epoxid, vinylester

\begin{abstract}
This paper deals with the problematics of polymer adhesive mortars. In this study, the vinyl ester and epoxy resins filled with siliceous filler were used. This paper studies physical-mechanical properties of developed mortars. The compressive strength, flexural strength, and abrasion resistance. The maximum filling ratio for each mortar was found while preserving the applicability in masonry way (by spatula). The results show that the amine-based epoxy mortar exhibits lower physical-mechanical properties than the vinylester-based adhesive mortar, except for the abrasion resistance, in which the epoxy-based composite has achieved significantly better results.
\end{abstract}

\section{Keywords}

Adhesive, polymer, epoxy, vinylester

\section{1 ÚVOD}

Polymerní lepicí malta je směs minerálního kameniva a polymerní pryskyřice, která nahrazuje portlandský cement a vodu jako pojivo v běžných opravných maltách. Polymerní malta vykazuje výrazně vyšší odolnost vůči celé řadě korozivních činidel a vykazuje vyšší pevnosti a nižší propustnost než běžné cementové opravné malty [1]. Nevýhodou polymerní malty je cena, která může být 100 - 200krát vyšší než u běžné cementové opravné či lepicí malty. Polymer-pryskyřičné lepicí a správkové malty lze použít např́klad také pro opravy konstrukcí z vysokopevnostních betonů jako náhradu chybějícího nebo zkorodovaného betonu s použitelností již 24-48 hodin po aplikaci. Některé polymery mohou být zatíženy i po výrazně kratší době (2-5 hodin). Epoxidové malty a polymerbetony jsou velmi důležité v současných aplikacích oprav betonových prvků, používají se také zároveň pro lepení oceli, betonu a různých, téměř veškerých materiálů. Například lokální trhliny na komunikacích a mostech lze opravit ve velmi krátké době a opravy vykazují velmi dobrou odolnost vůči široké škále zatížení, srovnatelné či přesahující parametry opravované konstrukce [2]. Některé polymerní pryskyřice lze pro dosažení požadované konzistence/zpracovatelnosti a snížení ekonomické náročnosti plnit až z $90 \%$ amorfními plnivy. Plniva se používají především pro snížení ekonomické náročnosti polymerních malt, zároveň však např́íklad pro zvýšení pevnosti v tlaku či chemické odolnosti [3]. V tomto článku bylo použito vodou ředitelné epoxidové pryskyřice a vinylesterové pryskyřice $\mathrm{k}$ př́ípravě lepicích malt a posouzení vybraných fyzikálně-mechanických vlastností. 


\section{POPIS SOUČASNÉHO STAVU}

Trend ve stavebnictví dnešní doby směřuje k využívání stále většího množství polymerních hmot. Tato skutečnost vyplývá především z nároků zákazníků na fyzikálně-mechanické vlastnosti stavebních hmot v kombinaci s co největším snížením spotřeby materiálu, zvýšení štíhlosti atd. Tento trend dále směřuje k co největšímu zkrácení např́iklad odstávek ve výrobě (polymerní hmoty mají obecně výrazně kratší dobu zrání než např. cementové správkové či lepicí hmoty), použití za nízkých teplot, použití ve velmi malých tloušt'kách při zachování vysokých odolností apod.

Nejvíce využívané polymerní materiály v dnešní době jsou na poli správkových a lepicích hmot epoxidy a polyestery. Oba materiály dosahují velmi vysokých fyzikálně-mechanických vlastností, vysoké hodnoty přídržnosti k betonu a dalším běžně využívaným materiálům, za relativně příznivé ekonomické náročnosti.

Polymerní materiály jsou ve stavebnictví využívány v celé řadě aplikací. Polymerní redispergovatelné prášky se využívají např́iklad pro úpravu vlastností cementových malt a betonů za účelem úpravy užitných vlastností (modifikace modulu pružnosti, přídržnosti, odolnosti apod.). Další druhy polymerů, mezi které patří například polyuretany, vinylestery, polyestery, epoxidy se využívají především pro výrobu správkových a lepicích malt.

Polymerní materiály se standardně plní pomocí inertních plniv s př́ídavkem pigmentů pro zajištění především vhodné konzistence pro daný typ použití výsledné hmoty. Primární suroviny využívaných polymerních hmot jsou standardně relativně nízko viskózní, nelze je tedy využít bez dalších úprav reologických vlastností využít pro všechny aplikace. Př́idavek plniv zároveň významným zpơsobem snižuje ekonomickou náročnost jinak velmi nákladných surovin.

V současné době je velká snaha opouštět od využívání primárních plniv, které se stávají nákladnými a zároveň jejich množství na světovém trhu ubývá. Zároveň se však zvyšuje významným způsobem snaha o recyklaci a druhotné využití odpadů, což vede současný výzkum $\mathrm{k}$ průzkumu dosud nezkoumaných surovin. Využití odpadů a druhotných surovin má za primární následek snížení ekonomické náročnosti vyráběných hmot, sekundárním účinkem je zvýšení poptávky po těchto produktech, z důvodu orientace dnešních zákazníků na environmentálněpř́iznivé produkty.

\section{MATERIÁLY A METODIKA}

$\mathrm{V}$ rámci této práce byla využita nízko viskózní vodou ředitelná epoxidová pryskyřice v kombinaci s polyaminovým tvrdidlem a epoxy-vinylesterová pryskyřice v kombinaci s methylethylketon peroxidovým tvrdidlem. Jako plnivo bylo využito odpadního písku s obsahem vodního skla z hutní výroby v kombinaci $\mathrm{s}$ železitým černým pigmentem.

\section{Epoxidová pryskyřice}

Pro výzkum v rámci této práce byla použita nízko viskózní diglycidyl ether epoxidová pryskyřice vyrobená kombinací bisphenolu A a F. K této pryskyřici bylo použito polyaminové tvrdidlo v poměru míchání 60 dílů pryskyřice, 40 dílů tvrdidla. Dle informací výrobce byla minimální doba zpracovatelnosti použité epoxidové pryskyřice (uváděná také jako pot life) 80 minut. Hustota pryskyřice smíchané $\mathrm{s}$ tvrdidlem byla $1,06 \mathrm{~g} \cdot \mathrm{cm}^{-3}$. Viskozita pojiva byla 500-800 mPas.

\section{Epoxy-vinylesterová pryskyřice}

Pro výzkum byla dále použita epoxy-vinylesterová pryskyřice. K této pryskyřici bylo použito methylethylketon peroxidové tvrdidlo v poměru míchání 98,75 dílů pryskyřice a 1,25 dílu tvrdidla. Dle informací výrobce byla minimální doba zpracovatelnosti použité epoxidové pryskyřice (uváděná také jako pot life) 30 minut. Hustota pryskyřice smíchané s tvrdidlem byla $1,05 \mathrm{~g} \cdot \mathrm{cm}^{-3}$. Viskozita pojiva byla $600-900 \mathrm{mPas}$.

\section{PInivo}

V rámci výzkumu byl využit jako plnivo do lepicích malt slévárenský písek s obsahem vodního skla, jakožto druhotná surovina $\mathrm{z}$ hutnického průmyslu o zrnitosti 0-500 $\mu \mathrm{m}$. Slévárenský písek s vodním sklem je materiál, který se používá jako bednicí materiál pro výrobu forem ve slévárně železa. Tento materiál lze po odbednění výrobků použít opakovaně, ale postupem času postupně degraduje vnášením nečistot, kousků železa a dalších cizích materiálů, které postupně snižují jeho kvalitu. Tento materiál je tvořen převážně velmi čistým křemenným pískem s obsahem $80-85$ hm. \% $\mathrm{SiO}_{2}$ a menším množstvím rozpustného skla (křemičitan sodný). V České republice 
se ročně vyrobí 30000 tun tohoto materiálu [4]. Plnivo bylo předupraveno pomocí čelist'ového drtiče na požadovanou zrnitost a následně bylo smícháno s 2 hm.\% černého železnatého pigmentu. Analýza granulometrie je znázorněna na Obr. 1.

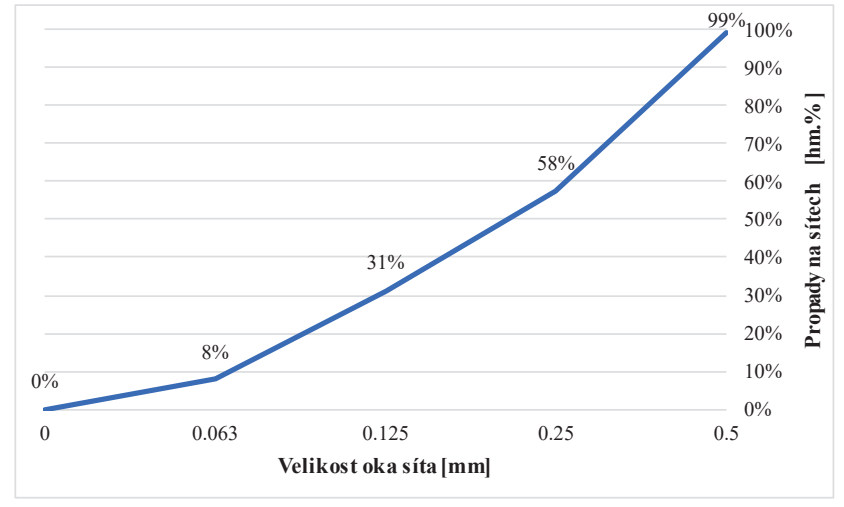

Obr. 1 Sítový rozbor použitého plniva.

\section{Formulace}

V rámci výzkumu bylo využito jednoduchých formulací, které sestávaly ze smíchání pojivové složky s předem zhomogenizovanou plnivovou složkou v poměru takovém, který zajištoval maximální míru naplnění při zachování zpracování zednickým zpo̊sobem (špachtlí či lžící).

\section{Receptury}

V rámci výzkumu byly stanoveny materiálové vlastnosti polymerních kompozitů u kterých byla stanovena maximální míra plnění při zachování zpracovatelnosti zednickým způsobem. V Tab. 1 jsou uvedeny použité receptury.

Tab. 1 Formulace receptur využitých v rámci výzkumu.

\begin{tabular}{ccc}
\hline Míra plnění & $\begin{array}{c}\mathbf{8 0} \text { hm.\% } \\
\text { EPOXID }\end{array}$ & $\mathbf{6 8 ~ h m . \% ~ V E S ~}$ \\
\hline Pryskyřice [hm. \%] & 12,0 & 31,6 \\
Tvrdidlo [hm. \%] & 8,0 & 0,4 \\
Plnivo včetně 2 hm.\% pigmentu [hm. \%] & 80,0 & 68,0 \\
\hline
\end{tabular}

\section{Metody}

Epoxidová pryskyřice i epoxy-vinylesterová pryskyřice byly smíchány s tvrdidly a důkladně promíchány elektrickým míchadlem při rychlosti přibližně 400 otáček za minutu po dobu 2 minut. Po této době bylo do směsi postupně přidáváno plnivo s železitým pigmentem. Materiál byl následně míchán jednu minutu, aby vznikla homogenní směs, kterou lze aplikovat zednickým způsobem.

\section{Pevnost v tlaku a v tahu za ohybu}

Pevnost v tlaku a v tahu za ohybu byla stanovována na vzorcích o rozměrech 20x20x100 mm. Pevnost v tlaku byla stanovována v souladu s ČSN EN 13892-2:2003 na vzorcích po stanovení pevnosti v tahu za ohybu pomocí př́ložek o velikosti 20x20 mm pro rovnoměrné rozložení síly laboratorního lisu po celé ploše vzorku. Pevnost v tahu za ohybu byla stanovována tříbodovým ohybem. Zkušební vzorky byly vyrobeny v počtu 3 ks od každé receptury. Vzdálenost podpor byla $80 \mathrm{~mm}$ [5]. 


\section{Př́́držnost k podkladu}

Přídržnost k podkladu byla stanovována pomocí laboratorního odtrhoměru na vzorcích aplikovaných na předem připravený prefabrikovaný betonový vzorek dlaždice. Př́idržnost k podkladu byla provedena po 7 dnech od zamíchání. Přídržnost k podkladu byla provedena v souladu s ČSN EN 1542:1999. Polymerní hmota byla nanesena ihned po zamíchání zednickým způsobem pomocí špachtle v tloušt'ce přibližně 3 mm. Zkušební vzorky byly vyrobeny v počtu 3 ks od každé receptury. Zrání polymerní hmoty probíhalo v laboratorním prostředí [6].

\section{Objemová hmotnost}

Objemová hmotnost připravených těles byla stanovována v souladu s ČSN EN ISO 845. Objemová hmotnost byla stanovena na laboratorních vzorcích o rozměrech 20x20x100 mm před stanovením pevnosti v tahu za ohybu [7]. Zkušební vzorky byly vyrobeny v počtu 3 ks od každé receptury.

\section{Odolnost proti obrusu}

Odolnost proti obrusu byla stanovena dle ČSN EN 13892-3:2003. Odolnost proti obrusu byla testována metodou Böhme. Z každé polymerní lepicí malty byly připraveny tři zkušební vzorky o rozměrech 70x70x50 mm [8].

\section{VÝSLEDKY}

V této kapitole jsou popsány výsledky dosažené v rámci výzkumu.

\section{Pevnost v tlaku a tahu za ohybu a objemová hmotnost}

Pevnosti v tlaku a tahu za ohybu jsou znázorněny v kombinaci s objemovou hmotností na Obr. 2.

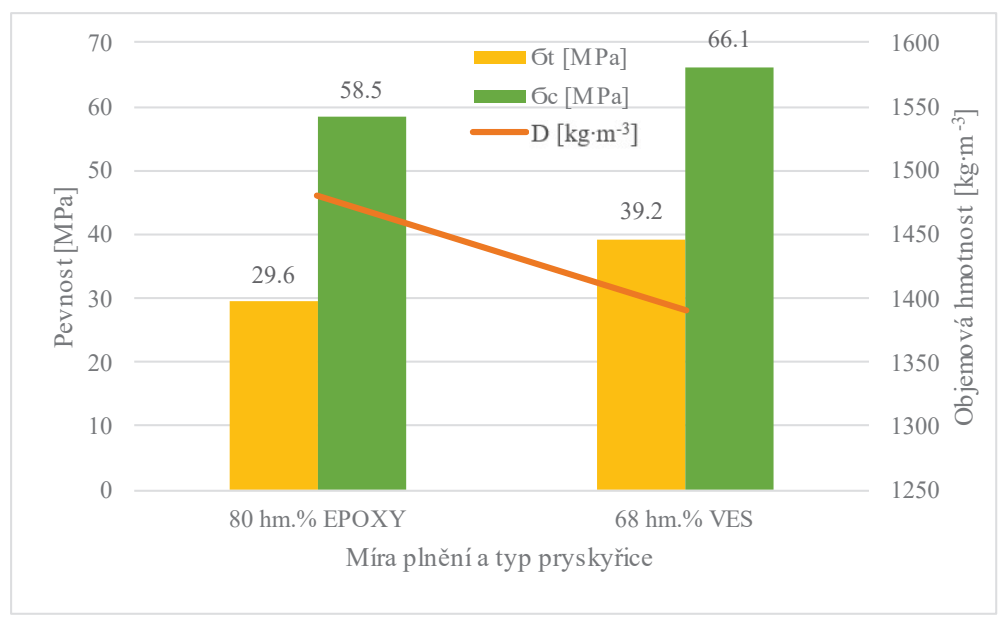

Obr. 2 Pevnost v tlaku, pevnost v tahu za ohybu a objemová hmotnost.

Na výše uvedeném obrázku obr. 2 je graficky znázorněna pevnost v tlaku, pevnost v tahu za ohybu a objemová hmotnost vzorků polymerní malty. Z grafu vyplývá, že polymerní kompozit na bázi epoxidové pryskyřrice vykazuje o 12-20 \% nižší pevnosti v tahu za ohybu a pevnosti v tlaku než polymerní kompozit $\mathrm{z}$ epoxyvinylesterové pryskyřice. 


\section{Př́́držnost k podkladu}

Přídržnost k podkladu testovaných vzorků kompozitních polymerních lepicích malt byla stanovena pomocí ručního laboratorního odtrhoměru DYNA. Přídržnost byla stanovována k podkladu z prefabrikovaného betonu. U všech testovaných vzorků došlo k porušení v podkladu při pevnosti vyšší než 3,2-3,5 MPa, kdy došlo k tahovému porušení podkladního betonu. Přídržnost lepicích malt je tedy dostačující pro většinu aplikací.

\section{Odolnost proti obrusu}

Odolnost proti obrusu připravených vzorků polymerních lepicích pryskyřic byla stanovena metodou Böhme na laboratorním brusném talíri. Výsledky odolnosti proti obrusu jsou uvedeny v následující tabulce (vyšší hodnota naměřená při stanovení odolnosti proti obrusu značí nižší odolnost proti obrusu)

Tab. 2 Výsledky odolnosti proti obrusu.

\begin{tabular}{|c|c|c|}
\hline Míra plnění a typ pryskyřice & 80 hm.\% & $68 \mathrm{hm} . \%$ VES \\
\hline & EPOXID & \\
\hline Odolnost proti obrusu $\left[\mathrm{cm}^{3} \cdot 50 \mathrm{~cm}^{-2}\right]$ & 6,28 & 5,56 \\
\hline
\end{tabular}

\section{ZÁVĚR}

V rámci této studie byly studovány rozdíly fyzikálně-mechanických vlastností epoxidové pryskyřice (bisphenol A/F) v kombinaci s polyaminovým tvrdidlem (PA) a epoxy-vinylesterové pryskyřice vkombinaci s methylethylketon peroxidovým tvrdidlem (MEKP). Součástí výzkumu bylo provedení stanovení maximální míry plnění při zpracovatelnosti zednickým způsobem (špachtlí či lžící). Tato byla byla stanovena pro epoxidovou lepicí maltu na $80 \mathrm{hm} . \%$ a pro epoxy-vinylesterovou lepicí maltu na $68 \mathrm{hm}$. \%. Rozdíly v maximální míře plnění jsou dány především rozdílnou viskozitou pryskyřic po zamíchání, kdy epoxidová pryskyřice vykazovala výrazně nižší viskozitu. Jako plnivo bylo využito druhotné suroviny z výroby forem v hutním průmyslu, křemenného písku s obsahem vodního skla. Toto plnivo bylo smícháno s $2 \mathrm{hm}$. \% železitého černého pigmentu. V rámci výzkumu bylo zjištěno, že epoxidová pryskyřice dosahuje i při výrazně vyšším plnění nižších pevností a to v tlaku ale také v tahu za ohybu. Přičemž předpoklad je, že polymerní pryskyřice at' už epoxidová, či epoxy-vinylesterová jsou nositeli především pevností v tahu za ohybu, kdežto plnivo je nositelem především pevností v tlaku. Ze stanovení přídržnosti k podkladu prefabrikovaného betonu bez použití adhezních můstků bylo zjištěno, že obě lepicí malty dosahují velmi vysokých př́ídržností a k porušení došlo u všech vzorků až ve chvíli, kdy došlo k porušení tahových pevností podkladního betonu. Zároveň ze stanovení odolnosti proti obrusu vyplývá, že epoxidová pryskyřice dosahuje také nižších odolností, než pryskyřice epoxy-vinylesterová.

\section{Poděkování}

Tento príspěvek byl podpořen projektem FAST-J-21-7318 „Studium správkových a lepicích hmot s vyšším obsahem druhotných surovin se zvýšenou odolností vưči extrémním zatížením pro obkladové prvky a betonové konstrukce".

\section{Použité zdroje}

[1] R. Bedi, R. Chandra and S. P. Singh, Mechanical Properties of Polymer Concrete, Journal of Composites. 2013, 1-12.

[2] X. Xie, X. Zhang, Y. Jin, and W. Tian, "Research Progress of Epoxy Resin Concrete", IOP Conference Series: Earth and Environmental Science, vol. 186, Sep. 2018.

[3] D. G. Walters, Polymer Concrete. Detroit: American Concrete Institute, 1993.

[4] BÍLEK, V. Možnosti využití odpadních písků z výroby vodního skla ve stavebnictví. Brno: Vysoké učení technické v Brně. Fakulta chemická. 2013.

[5] ČSN EN 13892-2: Zkušební metody potěrových materiálů - Část 2: Stanovení pevnosti v tahu za ohybu a pevnosti v tlaku. 2003. Praha: Český normalizační institut, 2003

[6] ČSN EN 1542: Výrobky a systémy pro ochranu a opravy betonových konstrukcí - Zkušební metody Stanovení soudržnosti odtrhovou zkouškou Praha: Český normalizační institut, 1999. ČSN EN 1542.

[7] ČSN EN ISO 845: Lehčené plasty a pryže - Stanovení objemové hmotnosti. 1/10. Praha, 2010.

[8] ČSN EN 13892-3: Zkušební metody potěrových materiálů - Část 3: Stanovení odolnosti proti obrusu metodou Böhme. 2014. Praha: Český normalizační institut, 2015 